\title{
Employee Engagement in Post COVID Era with Reference to IT Industry, Hyderabad
}

\author{
N Hima Bindu \\ Assistant Professor, MBA Department \\ Sridevi Women's Engineering College, Hyderabad
}

\begin{abstract}
Employee engagement is a key business driver for organizational success. Employee engagement is the level of enthusiasm and commitment an employee feels toward his/her job. Employee engagement is built on belief, reliability, commitment and communication between an organization and its adherents. Engaged employees lead to productivity in the workplace, and this generates higher customer satisfaction and positive rises in sales and also profits. Employee engagement is today seen as a powerful source of competitive advantage in the turbulent times. Organizations are constantly developing innovative and effective means to engage the employees during this tough time.
\end{abstract}

Organizations are evolving many engagement activities like online family engagement practices, virtual learning and development, virtual coffee breaks, gamification, online team building activities, webinars with industry experts, team meet-ups over video conference for lunch, short online game sessions, virtual challenges and competitions, online courses, appreciation sessions, communication exercises, live sessions for new-skill training, online counselling sessions, providing online guidance for exercise and meditation, elearning modules, and many more creative learning sessions. The objectives of this study - To analyse the impact of COVID-19 on employee engagement and to examine the various factors affecting employee engagement. The primary data is collected through google form where questionnaire is framed using five point rating scale and secondary data is collected through magazines, journals, company websites etc. The main purpose of this paper is to find how work-from-home regime engagement activities are very fruitful for employees as well as for organizations and what kind of engagement activities organisations are implementing for their employees for learning new skills and developing themselves. During this tough time of COVID-19 pandemic also employees are feeling committed to the organization and stay motivated.

Keywords: Employee Engagement, COVID-19, Competitive Advantage, Work from Home, Gamification

\section{Introduction}

A "dedicated employee" always works in a very hooked manner toward their job and responsibilities and promotes the interests of their organization. The commitment differs considerably from the worker satisfaction, the motivation, organizational structure and culture. It is the "emotional connect" that an employee shows towards its organization In engagement, employees interact and differentiate themselves physically, cognitively, and showing emotion throughout role conceptions. An obsessed employee strives to enhance performance at intervals in a team to achieve the goals of organization. The organization in order to maintain a reciprocal relationship between management and employees has to develop and promote employee engagement as a measuring system that determines the functioning of the organization. Engaging the personnel is "the extent to which employees commit to person or task in their organization, employee performance and retainment as a result of that commitment. Employees with more commitment levels perform $30 \%$ better and are $70 \%$ less likely to leave the organization. Employee engagement comprises two important facets, job engagement and organization engagement. An engaged employee continuously take care about their determination, work, and enactment, and employees want to feel that this could make a difference.

Employee engagements always support the organization to accomplish its mission, execute its strategy, and produce substantial business results. Organizations with employee engagement, cleverly manage talent, and 
communicate with employees honestly, precisely, and at the right time will drive the current market instability and be successful in the future. Career development programmes, encouragement, appreciation, flexible work hours, fair compensation structure, transparent work environment, and workmen participation in management are the factors contributing to employee engagement at the workplace. Employee engagement is a methodology that flourishes the chances of business accomplishment, promoting to overall organizational performance, productivity, and well-being of employees.

\section{COVID 19 Lockdown}

COVID-19 (SARS-CoV-2) belongs to a large group of corona virus family which causes severe respiratory illness. The first outbreak of corona virus is from the Wuhan city, located in the Hubei province, China in December 2019 .World Health Organization (WHO) officially declared it as a pandemic. The COVID-19 virus spreads primarily through droplets of saliva or ejection from the nose when an infected person coughs or sneezes. In this situation, most of the countries go for lockdown, so that spread of COVID-19 will break soon. Due to lockdown, most of the organizations provide the facility to their employees work from home. Most of the employees feel stressed due to work load, continuous meetings, work issues, increased working hours, network connectivity, salary and hike, performance assessments etc. They are not sure about their job security. Due to these difficulties, employees could not concentrate/focus on their work, so there is a need for employee engagement. The primary responsibility of the organization is to take care of their employees' well-being and engage them accurately. As a part of employee engagement HR professionals are conducting motivational talk lectures, boost their morale, and provide security and open environment so employees can raise their voice if they are having some issues. There should be transparent policy, so employees do not feel stress about their job and engage in their job well mannered.

For the IT sector, the work is not that much affected by the pandemic; only the work culture. Primarily, employees were enthusiastic about work from home, but they got bored at home with time. Employees could play games, go to cafes or just gossip during their breaks but now, they do their jobs or doze off during their breaks. Employees who are parents or are constant with their current jobs have more amiability towards work from home.

The employees even can't have their adventure trips, picnics, team gatherings, team lunch, and other interactive or engaging events that they usually waited for. In any virtual event, only the guests and the event coordinators can speak. The others who don't know each other in the same virtual room can't have personal interaction or conversation with each other.

\section{Factors affecting Employee Engagement}

\section{Job Satisfaction}

A satisfied employee will become a committed person. It is vital for a company to measure and analyse employee performance whether they achieve organisation mission and goals.

\section{Communication}

The organisation must adopt transparent policy. Communication ought to be up and down. Workmen participation in management is inculcated and also proved to be right by his superior, the engagement is probably high.

\section{Family Friendliness}

Work life balance of an individual influences his career. When employee realizes that the management giving importance to their family also, employee commitment and dedication will increase.

\section{The 10 Cs in Employee Engagement}

\section{Connect}

Employee engagement directly reflects employee- employer relationship. Having strong relationships with superiors create a sense of mentorship and strong employee engagement. 


\section{Career}

The employee strives hard to complete a complicate and necessary task with opportunities for occupation progression. Majority of employees need to try do new in their job .Employee aspires opportunity for growth and not a stagnant position which creates more employee motivation.

\section{Clarity}

Superiors should transmit information to subordinates in a clear and transparent manner so that they can achieve the goals and objectives in clear and concise manner.

\section{Convey}

Leaders in the organization need to convey employee roles clearly but also come back with better outcomes and impact employees in various successes.

\section{Congratulate}

Providing recognition to those who are beyond expectations to obtain the results companies are looking to accomplish.

\section{Contribute}

Organization should believe that their human assets contribution is very vital in achieving organizational goals. Employers facilitate employees to ascertain and contribute to the success.

\section{Control}

Employees always being controlled and coordinated by their superiors and providing opportunity in workmen's participation in management usually reduces stress.

\section{Collaborate}

Create teamwork in healthy competition, support, trust, and cooperation. Good team leaders encourage teamwork to maximize the potential of a department

\section{Credibility}

Companies that holds high ethical standards to represent their employees as credible and can create a strong sense of integrity.

\section{Confidence}

Good leaders build trust, high moral and performance standards. Create a sense of confidence within employees to help promote their future in the company.

\section{Top Trends of Employee Engagement}

1. Employee-employer relationship evolving/changing to partnerships.

2. Increased demand for work/life balance.

3. Growing emphasis on discerning preservation in order to maintain crucial staff.

4. Work spiralling as managers rise efficiency with less human assets.

5. Retaining most talented staff and shift to digital communication rather than old communication.

\section{Review of Literature}

Employee engagement can be used as a mediator for measuring the attitudes, intention, and conduct of employees to an improved work performance. (Andrew \& Sofian, 2012; Saks, 2006). Andrew and Saudah (2012) concluded that employee engagement can be utilized as a mediator to enhance the conduct, purpose, and assertiveness of employees toward a better work performance. Basquille (2013) recommended that managers should be supported by the executive to provide development assistance, career support, and recognition. Blessing White Organization developed a model for Employee Engagement by classifying the 
concept into five levels with reference to the level of individual contribution towards organizational achievement and satisfaction receive from the job.

\section{Engagement Levels of Employees}

Engaged - "Dedicated "Employees require to grasp the required expectations of their role to satisfy and exceed them, they're in fact intrusive about their company they maintain a systematically high level of talent and strengths work a day, they work with passion, drive innovation and drive their organization forward.

Almost Engaged - Employees with high performance and dedicated to their job and the levels will be determined by company gaols.

Fully Engaged - Utmost satisfaction with their position and compensation they receive and less importance to the success of the firm. They remain with the organisation for less time.

Disengaged - Employees strive hard for individual, team and organizational success career wise but feeling unhappy about personal life.

Strongly DisEngaged- Personnel with great levels of dissatisfaction and negative opinion on Company methodology of treating employees.

Macey et al. (2009) stated that employees with high levels of engagement are fully enthralled, intensively focused on the task. Such a state is referred as being "in the zone" or "in the flow" (highly engaged) and stated that bringing such a state is relatively exceptional.

\section{Enabling Engagement}

Robinson (2004) states the main influencing factors of job fulfilment are motivation at work, proper communiqué and learning methodology etc. Besides these main factors other factors like office atmosphere, beliefs, advancement, esteem etc. also influences employee satisfaction. The exemplary for employee engagement is:

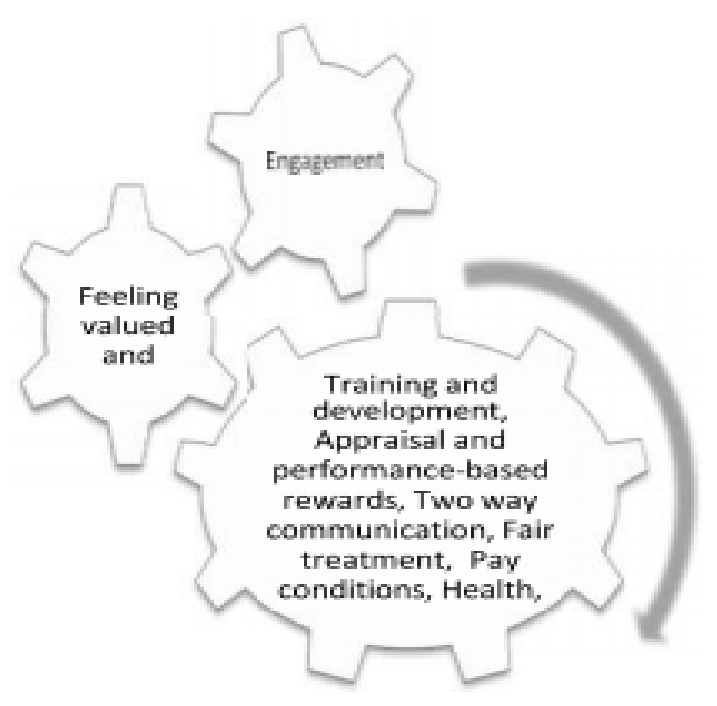

To preserve noble and devoted employees, organization must have a complete and sharing approach and governance qualities to report the trepidations of personnel and achieve them in a well-timed manner. Organization should incorporate worker growth for their occupation enrichment. By combining humble, liable, pre-emptive, cordial and concerned behavior towards employees.

Research Methodology: Primary data was conducted in the form of a survey. The Google form survey was conducted to contact the employees in IT industry. 100 respondents filled the Google form and sent. 


\section{Hypothesis testing}

Null Hypothesis (H0): There exists no relationship between employee engagement and productivity.

Alternative Hypothesis (H1): There is a relationship between employee engagement and productivity.

The mean of four counts is equally based on the null hypothesis. The group variance is roughly the same, the p-value is more than our significance level i.e., 0.05 , we accept the null hypotheses.

ANOVA

\begin{tabular}{|l|r|r|r|r|r|r|}
\hline Source of Variation & SS & df & MS & F & P-value & F crit \\
\hline Between Groups & 2110.53 & 4 & 527.6326 & 2.462032 & 0.062641 & 2.633532 \\
\hline Within Groups & 7715.079 & 36 & 214.3078 & & & \\
\hline & & & & & & \\
\hline Total & 9825.61 & 40 & & & & \\
\hline
\end{tabular}

Data Analysis:

\begin{tabular}{|l|c|c|c|c|c|}
\hline Parameters & Strongly Disagree & Disagree & Neutral & Agree & Strongly Agree \\
\hline $\begin{array}{l}\text { Employee engagement work in the long run for an } \\
\text { organization }\end{array}$ & & 10 & 60 & 20 & 10 \\
\hline $\begin{array}{l}\text { Organization can build team cohesiveness in virtual } \\
\text { environment }\end{array}$ & 20 & 40 & 10 & 10 & 20 \\
\hline $\begin{array}{l}\text { Organization engage employees at the same level working } \\
\text { from the office and some are working from home }\end{array}$ & & 10 & 10 & 40 & 40 \\
\hline $\begin{array}{l}\text { Maintaining Professional ethics in the organizations, which } \\
\text { are transitioning to a largely remote work culture }\end{array}$ & 40 & 10 & 10 & 20 & 20 \\
\hline $\begin{array}{l}\text { Organizational leaders were obligated to become agile in } \\
\text { the face of disruption }\end{array}$ & 15 & 10 & 15 & 20 & 40 \\
\hline $\begin{array}{l}\text { Employee perceptions of fair compensation and good } \\
\text { benefits }\end{array}$ & 50 & 20 & 10 & 15 & 15 \\
\hline $\begin{array}{l}\text { Improve the health and wellbeing of their workforces } \\
\text { during this chaotic and unprecedented time }\end{array}$ & & 50 & 40 \\
\hline $\begin{array}{l}\text { Managers driving team performance and having effective } \\
\text { performance conversation }\end{array}$ & 20 & 5 & 10 & 40 & 30 \\
\hline $\begin{array}{l}\text { Employee perceptions of safety guidelines should be put } \\
\text { into place }\end{array}$ & & 45 & 50 \\
\hline
\end{tabular}

\begin{tabular}{|l|r|r|r|r|}
\hline Anova: & \multicolumn{4}{|l|}{ Single Factor } \\
\hline Summary & & & & \\
\hline Groups & Count & Sum & Average & Variance \\
\hline Column 1 & 6 & 155 & 25.83333 & 244.1667 \\
\hline Column 2 & 9 & 125 & 13.88889 & 111.1111 \\
\hline Column 3 & 7 & 125 & 17.85714 & 348.8095 \\
\hline Column 4 & 9 & 300 & 33.33333 & 206.25 \\
\hline Column 5 & 10 & 275 & 27.5 & 206.9444 \\
\hline
\end{tabular}

\section{Findings}

The main purpose of the analysis is to understand employee engagement. Supported the analysis of descriptive statistics has been conferred. The hypotheses were developed to check the impact. The ANOVA Single factor was used to spot the mean and variance of many populations area unit equal. Major findings from the study area unit given below:

1. There exists no relationship between employee engagement and productivity. So, Null hypothesis is accepted. 
2. Majority of employees perceive that Organization can build team cohesiveness in virtual environment and engage employees at the same level working from office and are working from home.

3. Employees strongly believe that organizations continuously improving the health and wellbeing of their workforces during this chaotic and unprecedented time.

4. Employees somehow dissatisfied about fair compensation and good benefits and also increments should be handled fairly.

5. Motivation and communication is the appropriate and proficient consider about employee engagement and Productivity.

\section{Conclusion}

Today employee engagement is becoming very crucial as employees experience job insecurity, compensation issues, and psychological stress. Organizations recognize employee engagement is key to success during this unprecedented time. Organizations constantly trying to keep their employees satisfied and motivated through employee engagement practices. Many organizations adopting new technology and different kinds of employee engagement practices to improve productivity such as virtual team meetings, TED Talks, virtual coffee breaks, recognization, and rewards of employees. This paper summits that the employee association to managerial strategy and goals, acknowledgment for work well done, and a culture of learning and development foster high levels of engagement. It is vital for HR to foster positive, effective employees along with workplace policies that focus on employee well-being, health and work/life balance.

\section{References}

[1] Osborne, S.; Hammoud, Mohamad, S., 2017. Effective Employee Engagement in the Workplace. In International Journal of Applied Management and Technology 16 (1), pp. 50-67.

[2] Statista, 2020. Have you started working from home because of the coronavirus (Covid-19) pandemic? URL: https://www.statista.com/statistics/1105777/share-of-people-workingfrom-home-due-to-thecoronavirus-pandemic-finland/Accessed:25 April 2020.

[3] World Health Organization 2010. What is a pandemic? URL:

https://www.who.int/csr/disease/swineflu/frequently_asked_questions/pandemic/en/ Accessed: 31 March 2020.

[4] Employee Engagement, 2012 Benchmark Study, Right Management, Manpower Group.

[5] Trends in Global Employee Engagement, Aon Hewitt. (2013)

[6] Understanding and Developing Your (people) Assets, A White Paper on Employee Satisfaction, B2B.

[7] Engaging Employees For A Strong Recovery, Randstad.

[8] Engaging for Success: Enhancing Performance Through Employee Engagement

[9] Konrad, A. M. (2006, March/April). Engaging employees through high involvement work practices. Ivey Business Journal Online, 1-6, www.iveybusinessjournal.com.

[10] Vance, R. J. (2006). Effective practice guidelines: Employee engagement and commitment. Alexandria, VA: SHRM Foundation. 